\section{Evaluation of Inhaled Nitric Oxide Use in Patients with Pediatric Acute Respiratory Distress Syndrome}

\author{
Pediatrik Akut Respiratuar Distres Sendromu Tanılı \\ Hastalarda inhale Nitrik Oksit Kullanımının \\ Değerlendirilmesi
}

Gülhan Atakul ๑ Gökhan Ceylan ๑ Ferhat Sarı $\odot$ Özlem Saraç Sandal ๑ Sevgi Topal ๑ Mustafa Çolak • Utku Karaarslan $\odot$ Hasan Ağın ๑

\section{ABSTRACT}

Objective: Nitric oxide therapy is not routinely used in the treatment of pediatric acute respiratory distress syndrome (PARDS), but it is recommended to be used as an adjunctive therapy in some selected cases. In our study, we aimed to discuss patients with PARDS who were treated with inhaled nitric oxide (iNO) therapy.

Methods: The data of patients who were hospitalized in the pediatric intensive care unit with a diagnosis of PARDS and received iNO treatment between January 2016 and January 2018 were retrospectively analyzed. Age, gender, length of stay, mortality, number of days on mechanical ventilation, use of vasoactive drugs, mortality scores, lactate levels, $\mathrm{Ol}$ (oxygenation index), $\mathrm{PaO}_{2} / \mathrm{FiO}_{2}$, methemoglobin levels, iNO administration time, echocardiographic findings and underlying primary diseases were recorded.

Results: It was determined that 9 patients who were followed up with the diagnosis of PARDS were given iNO treatment. Except for one patient, they were diagnosed with pneumonia developing on the basis of chronic disease and PARDS secondary to septic shock. Five patients died while receiving iNO therapy. Seven patients were ventilated with iNO in addition to conventional mechanical ventilation methods. Two patients who died were ventilated with HFOV (high frequency oscillatory ventilation). In 3 of 9 patients, inhaled nitric oxide treatment was successful.

Conclusion: Although inhaled nitric oxide treatment is a known treatment used in different diseases, the level of its effect in PARDS patients continues to be investigated. We think that this treatment can be beneficial when applied in selected patients and experienced centers.

Keywords: Pediatric acute respiratory distress syndrome, inhale nitric oxide, pediatric intensive care unit

öz

Amaç: Inhale nitrik oksit (iNO) tedavisi, pediatrik akut respiratuar distres sendromu (PARDS) tedavisinde rutin kullanılmamakla beraber bazı seçilmiş vakalarda ek tedavi yöntemi olarak kullanılması önerilen bir tedavidir. Çalışmamızda inhale nitrik oksit tedavisi alan PARDS tanılı hastaları tartışmayı amaçladık.

Yöntem: Ocak 2016 - Ocak 2018 tarihleri arasında çocuk yoğun bakım ünitesinde yatan PARDS tanısı INO tedavisi alan ve alan hastaların dosyaları geriye dönük olarak incelendi. Yaş, cinsiyet, kalışsüresi, mortalite, mekanik ventilasyonda geçen gün sayısı, vazoaktif ilaç kullanımı, mortalite skorları, laktat seviyeleri, OI (oksijenasyon indeksi), $\mathrm{PaO}_{2} / \mathrm{FiO}_{2}$ oranı, methemoglobin düzeyleri, iNO uygulama süresi, ekokardiyografik bulgular ve altta yatan birincil hastalıklar kaydedildi.

Bulgular: PARDS tanısıyla izlenen 9 hastaya iNO tedavisi uygulandığı saptandı. Bir hasta hariç diğerleri kronik hastalık zemininde gelişen pnömoni ve septik şoka sekonder PARDS tanısı almışlardı. Beş hasta, iNO tedavisi alırken eksitus geliști. Yedi hasta konvansiyonel mekanik ventilasyon yöntemlerine ek olarak iNO ile solutuldu. Eksitus olan 2 hasta HFOV (high frequency oscillatory ventilation) ile solutuldu. 9 hastanın 3 'ünde inhale nitrik oksit tedavisi başarılı olmuştu.

Sonuç: Inhale nitrik oksit tedavisi farklı hastalıklarda kullanılan bilinen bir tedavi olmasına rağmen, PARDS hastalarındaki etki düzeyi araştırılmaya devam etmektedir. Seçilmiş hastalarda ve deneyimli merkezlerde uygulandığında bu tedavinin faydalı olabileceğini düşünüyoruz.

Anahtar kelimeler: Pediatrik akut respiratuar distres sendromu, inhale nitrik oksit, pediatrik yoğun bakım ünitesi
Received: 14.01 .2020

Accepted: 29.10 .2020

Published Online: 30.04 .2021

Cite as: Atakul G, Ceylan G, Sarı F, Saraç Sandal Ö, Topal S, Çolak M, et al. Evaluation of inhaled nitric oxide use in patients with pediatric acute respiratory distress syndrome. İzmir Dr. Behçet Uz Çocuk Hast. Dergisi. 2021;11(1):94-100.

Gülhan Atakul

S.B.Ü Dr. Behçet Uz Çocuk Hastalıkları ve Çocuk Cerrahisi,

İzmir, Türkiye

gulhanatakul@gmail.com ORCID: 0000-0002-3832-9691

G. Ceylan 0000-0002-1730-6968 F. Sarı 0000-0002-9134-767X

Ö. Sarac Sandal 0000-0003-2684-0625

S. Topal 0000-0002-7725-5509

M. Çolak 0000-0001-8310-3766

U. Karaarslan 0000-0002-3267-6983

H. Ağın 0000-0003-3306-8899

S.B.Ü Dr. Behçet Uz Çocuk Hastalıkları ve Çocuk Cerrahisi, izmir, Türkiye 


\section{INTRODUCTION}

Pediatric acute respiratory distress syndrome (PARDS) was presented at PALICC (Pediatric Acute Lung Injury Consensus Conference), revised and classified in 2015 with its latest definition. PARDS is a picture that causes severe hypoxemic respiratory failure by causing pulmonary gas exchange disorder. Healthy lungs regulate fluid movement by protecting alveoli with a small amount of interstitial fluid. However, with lung damage, excess fluid accumulation begins in the interstitium and alveoli. This results in impaired gas exchange, decreased compliance, and increased pulmonary artery pressure. One of the most important features of PARDS is hypoxemia and is associated with the severity of the disease ${ }^{(1-3)}$. In pediatric patients, treatment planning is made by calculating the oxygenation index with arterial blood gas measurement ${ }^{(4)}$. Inhaled nitric oxide (iNO) is successfully applied in the treatment of PPH (persistent pulmonary hypertension), especially in newborns and is a molecule that can cause relaxation in vascular smooth muscles and consequently vasodilation ${ }^{(5)}$. It is used as a supportive agent in selected PARDS cases to benefit from vasodilation and vascular regeneration effects. Also iNO, $T_{h}$ ( $T$ helper) is also known to reduce the inflammatory response by changing balance on cells. This immunomodulatory effect is also considered as the mechanism of action that can benefit patients with PARDS ${ }^{(6)}$. In this study, we wanted to share our experiences on iNO recovery therapy used in selected PARDS cases, not a routine treatment.

\section{MATERIAL and METHOD}

In the Dr. Behcet Uz Pediatric Diseases and Surgery Training and Research Hospital pediatric intensive care unit, there are 24 pieces of 3rd-stage pediatric intensive care beds, 2 pediatric intensive care specialists, 5 pediatric intensive care minor assistants, 5 pediatric assistants and 49 nurses. In our hospital, specialist training is given in both the branch of pediatric health and diseases and the fellowship of pediatric intensive care. The annual number of patient hospitalizations in our unit is around 300 patients.

The study was performed by retrospectively examining the files in our pediatric intensive care unit between 2016-2018, diagnosed with PARDS and undergone iNO treatment. The ethics committee file of our study was approved by the ethics committee

unit of our hospital with the number of 2019/357.

Each patients' age, gender, duration of ICU stay (days), mortality, number of mechanical ventilator days, vasoactive drug use, mortality scores (PRISM IV, pSOFA), baseline lactate levels, baseline OI (oxygenation index), baseline $\mathrm{PaO}_{2} / \mathrm{FiO}_{2}$ (partial arterial oxygen pressure/fraction of inspired oxygen) rate, methemoglobin levels measured at follow-up, duration of iNO administration, echocardiographic findings, underlying diseases were recorded.

Pediatric ARDS diagnostic criteria are determined as; findings of new involvement in the lung parenchyma with lung injury developing in the last 7 days, the rate of arterial oxygen saturation $\left(\mathrm{SpO}_{2}\right)$ to the fraction of inspired oxygen $\left(\mathrm{FiO}_{2}\right)$ being as $\leq 264$ and the ratio of $\mathrm{PaO}_{2}$ to $\mathrm{FiO}_{2}$ being as $\leq 300$ under the support of non-invasive and invasive mechanic ventilation; provided that the are not related to the perinatal period. In addition to these criteria, new cases of lung parenchyma involvement that cannot be explained by these diseases are among the diagnostic criteria in patients with cyanotic congenital heart diseases, chronic lung diseases and left ventricular dysfunction. After diagnosis of pediatric ARDS, oxygenation index and $\mathrm{PaO}_{2} / \mathrm{FiO}_{2}$ measurements are calculated for severity grading and decision of treatment modalities. The oxygenation index $\left(\mathrm{FiO}_{2} \times\right.$ mean airway pressure $\left.\times 100 / \mathrm{PaO}_{2}\right)$ is calculated by the formula ${ }^{(4)}$. All patients in our study were diagnosed with PARDS according to these criteria.

Inhaled nitric oxide treatment was initiated in cases where adequate oxygenation could not be achieved with conventional mechanical ventilation strategies (cases with $\mathrm{PaO}_{2} / \mathrm{FiO}_{2} \leq 110$ and $\left.\mathrm{Ol}>16\right)^{(4,7)}$. Inhaled nitric oxide treatment was applied intratracheally and continuously during mechanical 
ventilation with NOxBOX (Kent, England) brand device. Treatment was initiated at a dose of $5 \mathrm{ppm}$. The dose was increased to maximum $25 \mathrm{ppm}$ according to clinical response ${ }^{(8)}$. Following the initiation of inhaled nitric oxide treatment and ensuring adequate oxygenation, adjustments were made to $\mathrm{FiO}_{2}$, $\mathrm{PEEP}$ and volume targets in conventional mechanical ventilation settings. In patients who received inhaled nitric oxide treatment for at least 24 hours, and in cases where it did not benefit before exitus, or in case of improvement, the iNO level was gradually decreased down to $5 \mathrm{ppm}$ and cut according to the patient's MV settings and OI (Figure 1). Although the daily methemoglobin levels of patients receiving inhaled nitric oxide therapy should be monitored, we also evaluated methemoglobinemia along with oxygenation parameters by taking blood gases 4 times with an interval of 6 hours depending on the clinical status of our patients. Values lower than $5 \%$ were considered appropiate for methemoglobin ${ }^{(8)}$. All of our patients were evaluated with echocardiography by cardiology department before iNO treatment for the risk of developing pulmonary hypertension secondary to lung injury. However, in our study, patients' other accompanying heart failure, other therapies used for heart failure and other pulmonary hypertension treatment methods were not evaluated.

\section{RESULTS}

It was found that 9 patients who were monitored with the diagnosis of PARDS in pediatric intensive care were given iNO treatment. Demographic data, hospitalization, mortality scores and blood lactatemethemoglobin levels of the patients are shown in Table 1. Five of the patients were male and four were female. Their ages ranged from 2 months to 204 months. Except for one patient, the others were diagnosed with PARDS secondary to septic shock and pneumonia developing on the basis of chronic disease. In one patient, there was no known chronic disease and it was followed up in our clinic primarily with the diagnosis of PARDS secondary to acute community-acquired lower respiratory tract infection.

Mechanical ventilator variables, oxygenation parameters and measurements (before iNO) of the patients are given in Table 2 .

Duration of stay in the mechanical ventilator, vasoactive drug use, diagnosis of pulmonary hypertension (PH) by echocardiography, duration of iNO treatment and prognosis are shown in Table 3 for all patients.

Methemoglobin level was measured at a maximum of $1.8 \%$. The number of patients diagnosed $\mathrm{PH}$ (pulmonary hypertension) by echocardiography was 3 (cases 4,8,9). Patients with a pulmonary gradient of $25 \mathrm{mmHg}$ and above measured from the

Table 1. Demographic data, mortality scores and blood lactate-metHB levels of cases.

\begin{tabular}{|c|c|c|c|c|c|c|c|c|}
\hline $\begin{array}{l}\text { Patient } \\
\text { No }\end{array}$ & $\begin{array}{c}\text { Age } \\
\text { (months) }\end{array}$ & Gender & Diagnosis & $\begin{array}{l}\text { Length of stay } \\
\text { (day) }\end{array}$ & $\begin{array}{c}\text { PRISM IV } \\
\text { (Score/percent) }\end{array}$ & pSOFA & $\begin{array}{l}\text { Blood lactate level } \\
\text { (mmol/L) }\end{array}$ & $\begin{array}{c}\text { MetHB } \\
(\%)\end{array}$ \\
\hline 1 & 8 & Male & $\begin{array}{l}\text { Severe combined } \\
\text { immunodeficiency }\end{array}$ & 56 & $28(73.4)$ & 11 & 2.6 & 1.3 \\
\hline 2 & 24 & Male & Neurometabolic Disease & 5 & $22(44.3)$ & 9 & 1.5 & 1.8 \\
\hline 3 & 6 & Male & $\begin{array}{l}\text { Severe combined } \\
\text { immunodeficiency }\end{array}$ & 15 & $26(64.6)$ & 12 & 3.5 & 1.8 \\
\hline 4 & 48 & Female & Mucopolysaccharidosis type1 & 78 & $24(54.6)$ & 11 & 1.8 & 1.1 \\
\hline 5 & 12 & Female & Acute lymphocytic leukemia & 5 & $26(64.6)$ & 10 & 1.9 & 1.5 \\
\hline 6 & 7 & Male & No Chronic Diseases & 18 & $17(22)$ & 7 & 3.4 & 1.4 \\
\hline 7 & 24 & Female & Metabolic disease & 76 & $18(25.8)$ & 8 & 1.5 & 1.3 \\
\hline 8 & 204 & Female & $\begin{array}{l}\text { Cellular type immune } \\
\text { deficiency }\end{array}$ & 27 & $24(54.3)$ & 10 & 1.4 & 1.7 \\
\hline 9 & 2 & Male & Intracranial Hemorrhage & 3 & $20(35.7)$ & 10 & 4.5 & 1.2 \\
\hline
\end{tabular}

Pediatric Risk of Mortality (Prism IV), The Pediatric Sequential Organ Failure Assessment (pSOFA), MetHB (Methemoglobin percentage). 
Table 2. Mechanical ventilator parameters and measurements of patients.

\begin{tabular}{|c|c|c|c|c|c|c|c|c|}
\hline & Mv mode & Mv (day) & iNO initial peak & iNO initial MAP & OI & $\mathrm{PaO}_{2} / \mathrm{fiO}_{2}$ & Additional treatment & iNO initial PEEP \\
\hline 1 & VC-SIMV & 46 & 38 & 24 & 28 & 85 & HFO & 14 \\
\hline 2 & VC-SIMV & 5 & 40 & 24 & 30 & 80 & - & 13 \\
\hline 3 & PC-SIMV & 10 & 35 & 22 & 21 & 103 & HFO & 13 \\
\hline 4 & VC-SIMV & 20 & 36 & 22 & 18 & 118 & - & 12 \\
\hline 5 & PC-SIMV & 4 & 42 & 25 & 35 & 70 & - & 15 \\
\hline 6 & VC-SIMV & 10 & 32 & 20 & 22 & 90 & - & 12 \\
\hline 7 & VC-SIMV & 15 & 37 & 23 & 26 & 72 & - & 13 \\
\hline 8 & PC-SIMV & 4 & 38 & 22 & 20 & 110 & - & 14 \\
\hline 9 & VC-SIMV & 2 & 36 & 20 & 33 & 60 & - & 12 \\
\hline
\end{tabular}

VC-SIMV (Volume-controlled synchronized intermittent mandatory ventilation), PC-SIMV (Pressure-controlled synchronized intermittent mandatory ventilation), iNO (inhaled nitric oxide), OI (Oxygenation index), $\mathrm{PaO}_{2} / \mathrm{FiO}_{2}$ (partial arterial oxygen pressure /fraction of inspired oxygen), iNO (inhaled nitric oxide), MAP (mean airway pressure).

Table 3. Duration of therapy, vasoactive drug use and prognosis.

\begin{tabular}{|c|c|c|c|c|c|}
\hline Patient No & MV period (hours) & Vasoactive drug & Echocardiographic PH diagnosis & iNO Duration (Hour) & Mortality (result) \\
\hline 1 & 1100 & + & - & 638 & Yes \\
\hline 2 & 116 & + & - & 91 & Yes \\
\hline 3 & 236 & + & - & 88 & Yes \\
\hline 4 & 710 & + & + & 475 & No \\
\hline 5 & 91 & + & - & 70 & Yes \\
\hline 6 & 232 & + & - & 156 & No \\
\hline 7 & 353 & + & - & 114 & No \\
\hline 8 & 90 & + & + & 45 & Yes \\
\hline 9 & 47 & + & + & 10 & Yes \\
\hline
\end{tabular}

iNO: inhaled nitric oxide, MV: Mechanical ventilator, PH: Pulmonary hypertension.

tricuspid valve were considered meaningful for $\mathrm{PH}$. Pulmonary gradient measured in other patients was calculated as normal $(<25 \mathrm{mmHg})$. The EF (ejection fraction) values were minimum $58 \%$, maximum $75 \%$, average $65 \%$ ( \pm SD 1.8).

The iNO treatment of our patients was started with $5 \mathrm{ppm}$ and the maximum dose was up to 25 $\mathrm{ppm}$. In the reduction phase, it is reduced by $5 \mathrm{ppm}$ every 6-8 hours and treatment was discontinued at the 3ppm level (Figure 1). In five patients, while iNO treatment continued at a dose of $20-25 \mathrm{ppm}$, the exitus developed.

In our study, 7 patients were ventilated with conventional mechanical ventilation methods and cases number " 1 " and " 3 " were ventilated with HFOV (high frequency oscillatory ventilation) with iNO treatment. The patients were diagnosed with PARDS according to the PARDS diagnostic criteria in PALICC. In the follow-up of these patients, despite the use of $100 \%$ oxygen and high MV pressure levels, if oxygen saturation could not be increased above $85 \%$ or Ol was higher than 16 and $\mathrm{PaO}_{2} / \mathrm{FiO}_{2}$ was lower or equal to 110, iNO treatment has been initiated. Except for cases 6 and 9, our patients who received inhaled nitric oxide treatment had no indication for ECMO due to their underlying diseases and current iNO treatment was continued. Patient number nine died due to additional morbidity other than PARDS and the clinical status of the patient was not suitable for ECMO due to intracranial hemorrhage during approximately 10 hours of follow-up. The other patient, who did not have any chronic disease but developed PARDS secondary to pneumonia, was successfully treated with the correct MV strategy and additionally inhaled nitric oxide treatment, and was disconnected from the ventilator and discharged. In the clinical follow-up of this patient, ECMO was considered before the start of iNO, but iNO treatment 
$\mathrm{PaO} 2 / \mathrm{FiO} 2<150$

\section{Ol $>15$}

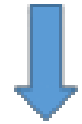

$\mathrm{PH}$ evaluation by echocardiography

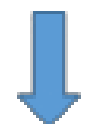

iNO treatment was started at a dose of $5 \mathrm{ppm}$.

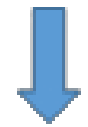

Increased every 10 minutes until SaO2> 20\% increase (max: 25ppm).

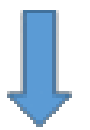

If there is a $\mathrm{PaO} 2>20 \%$

improvement, the start was

reduced by $3-5 p p m$.

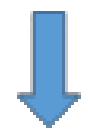

\section{It was cut by decreasing to $3 \mathrm{ppm}$} with evaluations of 6-8 hours.

$\mathrm{PaO}_{2} / \mathrm{FiO}_{2}$ : Partial arterial oxygen pressure/fraction of inspired oxygen, PH: Pulmonary Hypertension

Ppm: One unit per million; parts per million

Figure 1. iNO treatment algorithm.

was continued due to the rapid response to conventional MV therapy administered with iNO and improvement in blood gas oxygenation levels.

It was observed that vasoactive drugs were used in all of our patients. A case of multiorgan failure developing secondary to PARDS clinic developed in cases 1, 3, 6 and 9. The inotropic need of all patients supports the clinical picture that patients were accompanied by septic shock and cardiogenic shock. In 4 of our patients (cases 1,3,5,8) who died, primary or secondary developing immune deficiencies were present and they were at risk for infection. In addition to these cases, inotropic treatment was implemented in cases 6 and 9 due to septic shock. In our patients number 2, 4 and 7, inotropic treatment was given when systolic dysfunction was observed besides the existing neurometabolic disease.

It was observed that the findings of one of the three patients who were diagnosed with $\mathrm{PH}$ by echocardiography and received iNO treatment regressed (case 4 ) and two patients resulted in exitus (cases 8, 9). Of the 6 patients who were not diagnosed with $\mathrm{PH}$ echocardiographically, 2 were successfully treated and discharged, and the other 4 resulted in exitus.

\section{DISCUSSION}

Inhaled nitric oxide treatment; Although it is not recommended to use routine in adult ARDS and pediatric ARDS for the last 20 years, it is an accepted treatment method for rescue from extracorporeal life support or for bridging in severe PARDS cases. When the treatment options of our patients were evaluated, it was seen that inhaled nitric oxide treatment could be an important option as a savior in the PARDS developed on the basis of chronic disease. In our study, the high mortality rate was attributed to the fact that the severe baseline clinical features of the patients we lost due to their existing diseases were more severe compared to other patients.

Inhaled nitric oxide causes vasodilation by increasing cGMP (cyclic guanosine monophosphate) on pulmonary vascular smooth muscle. Pulmonary vasodilation reduces intrapulmonary shunt, improves ventilation/perfusion rate and improves oxygenation. Vasodilation effect is utilized in pulmonary hypertension ${ }^{(9)}$. One of the known side effects of inhaled nitric oxide is that it may cause coagulopathy 
because it induces partial inhibition of platelet aggregation ${ }^{(10,11)}$. In our study, none of the nine patients had coagulopathy. In our case with intracranial hemorrhage, this was a condition that developed independently before the iNO treatment. In our study, iNO doses not exceeding 25 ppm may be a reason why methemoglobinemia didn't develop. In the literature, this risk has been reported to increase at doses of $40 \mathrm{ppm}$ and above (12). In addition, there is no definite information about the maximum duration of iNO treatment. In the reports for the usages of INO due to PPHN with newborns, it was stated that it was used for 14 days and it was suggested to investigate the causes of alveolar capillary dysplasia in longer periods ${ }^{(13)}$. In patients 1 , 4 , and 6 of our patients, iNO treatment was continued for more than 7 days, as we considered the pathogenesis of PARDS, apart from its benefit for PH, and we saw an improvement in oxygenation. In meta-analyzes from adult studies, it has been reported that iNO treatment provides improvement in oxygenation in the first 24 hours $\left(\mathrm{PaO}_{2} / \mathrm{FiO}_{2}\right)$, while in some studies this period could be extended up to 96 hours ${ }^{(14,15)}$.

Epidemiologically evaluated, studies show that ARDS is less common in children than adults, compared with pediatric ARDS, high mortality may be due to higher incidence of multiple organ failure in adults, whereas in children, respiratory failure due to lung pathology is observed rather than multiple organ failure. It may be thought that lung selective treatment may provide more survival advantages in children than adults ${ }^{(9,16,17)}$.

Studies on recovery treatments for pediatric acute respiratory distress syndrome are also ongoing. Despite published inadequate meta-analysis, it has been reported that combinations of HFOV, prone position treatments and iNO use may be more effective than monotherapy ${ }^{(18)}$. In our patients, prone positions were applied in combination with iNO in others (due to the risk and difficulty in positioning) except in cases number 8 and 9 . A daily prone position duration of 10-12 hours was targeted and a change of position was applied every 4-6 hours.

In a meta-analysis in adults, 12 studies were examined and the effect of nitric oxide on ARDS was investigated in 1237 patients in total. As a result, it was concluded that routine use in acute lung injury (ALI) and acute respiratory distress syndrome does not have a positive effect on mortality. It is stated in the same meta-analysis that there may be some factors that can cause this situation. The first of these factors is that lung damage is not the only reason for the deterioration in oxygenation, and additional morbidity could be a contributing agent as well, the second, cause of mortality of patients is multiple organ failure rather than refractory hypoxemia and the third factor is that the MV strategies applied during iNO treatment damaged the lung and the effects of iNO treatment could be overwhelmed by the lung damage (19). The development of multiple organ failure also increases mortality in patients with pediatric acute respiratory distress syndrome. Causes of mortality of the PARDS patients who use inhaled nitric oxide can also be examined separately and the level of primary effects of hypoxemia on mortality should be investigated. In addition to the implementation of lung-specific treatments, treatment of the underlying disease is also required. As one of the reasons for not benefiting from inhaled nitric oxide treatment, it should be considered that there may be lung damage due to recurrent hospitalization and mechanical ventilation in children with chronic disease.

In PARDS patients with pulmonary hypertension and right ventricular dysfunction, iNO therapy should be considered as a bridge or rescue therapy. Depending on the patient's clinical condition and response, it can be predicted that this treatment before ECMO may benefit mortality, considering that it can improve hypoxia in a short time.

As a result; As said in the pediatric acute lung injury consensus conference (PALICC) recommendations, not as a routine, iNO was used only in selected PARDS cases that we monitored in our clinic. In the development of PARDS treatments in children, every clinic should share the treatment preferences they have applied and experienced in line with international guidelines and treatment modalities should be strengthened. We think that 
more data should be collected in order to better understand the issue of which patients can benefit in the pediatric age group and the role of iNO.

Ethics Committee Approval: S.B.Ü İzmir Dr. Behçet Uz Pediatric Diseases and Surgery Training and Research Hospital Clinical Research Ethics Committee approval was obtained (19.12.2019/17-08).

Conflict of Interest: The authors declared no potential conflicts of interest with respect to the research, authorship and/or publication of this article.

Funding: The authors received no financial support for the research, authorship, and/or publication of this article.

Informed Consent: Since the study design was retrospective and data were collected anonymously, informed consent was waived.

\section{REFERENCES}

1. Dantzker DR, Brook CJ, Dehart P, Lynch JP, Weg JG. Ventilationperfusion distributions in the adult respiratory distress syndrome. Am Rev Respir Dis. 1979;120(5):1039-52.

2. Roupie E, Dambrosio M, Servillo G, Mentec H, el Atrous S, Beydon $L$, et al. Titration of tidal volume and induced hypercapnia in acute respiratory distress syndrome. Am J Respir Crit Care Med. 1995;152(1):121-8. https://doi.org/10.1164/ajrccm.152.1.7599810

3. Vieillard-Baron A, Schmitt JM, Augarde R, Fellahi JL, Prin S, Page $B$, et al. Acute cor pulmonale in acute respiratory distress syndrome submitted to protective ventilation: incidence, clinical implications, and prognosis. Crit Care Med. 2001;29(8):1551-5.

https://doi.org/10.1097/00003246-200108000-00009

4. Khemani RG, Smith LS, Zimmerman JJ, Erickson S, for the Pediatric Acute Lung Injury Consensus Conference Group. Pediatric acute respiratory distress syndrome: definition, incidence, and epidemiology. Proceedings from the pediatric acute lung injury consensus conference. Pediatr Crit Care Med. 2015;16(5 Suppl 1):S23-40.

https://doi.org/10.1097/PCC.0000000000000350

5. American Academy of Pediatrics. Commitee on Fetus and Newborn. Use of inhaled nitric oxide. Pediatrics. 2000;106:344-5.

https://doi.org/10.1542/peds.106.2.344

6. Mannick JB. Immunoregulatory and antimicrobial effects of nitrogen oxides. Proc Am Thorac Soc. 2006;3:161-5. https://doi.org/10.1513/pats.200505-048BG

7. Alessandri F, Pugliese F, Ranieri VM. The Role of Rescue Therapies in the Treatment of Severe ARDS. Respir Care.
2018;63(1):92-101.

https://doi.org/10.4187/respcare.05752

8. Gebistorf F, Karam O, Wetterslev J, Afshari A. Inhaled nitric oxide for acute respiratory distress syndrome (ARDS) in children and adults. Cochrane Database Syst Rev. 2016;(6):CD002787. https://doi.org/10.1002/14651858.CD002787.pub3

9. Juliette LH, Ronald AB, Nick to. Role of Inhaled Nitric Oxide in the Management of Severe Acute Respiratory Distress Syndrome. Front Pediatric. 2016;4:74. https://doi.org/10.3389/fped.2016.00074

10. Radomski MW, Moncada S. Regulation of vascular homeostasis by nitric oxide. Thromb Haemost. 1993;70(1):3641. https://doi.org/10.1055/s-0038-1646156

11. Samama CM, Diaby M, Fellahi JL, Mdhafar A, Eyraud D, Arock $M$, et al. Inhibition of platelet aggregation by inhaled nitric oxide in patients with acute respiratory distress syndrome. Anesthesiology. 1995;83(1):56-65. https://doi.org/10.1097/00000542-199507000-00007

12. Weinberger B, Laskin DL, Heck DE, Laskin JD. The toxicology of inhaled nitric oxide. Toxicol Sci. 2001;59:5. https://doi.org/10.1093/toxsci/59.1.5

13. Kinsella JP, Abman SH. Clinical approach to inhaled nitric oxide therapy in the newborns with hypoxemia. J Pediatr. 2000;136:717-26. https://doi.org/10.1016/S0022-3476(00)10660-2

14. Afshari A, Brok J, Moller AM, Wetterslev J. Inhaled nitric oxide for acute respiratory distress syndrome and acute lung injury in adults and children: a systematic review with metaanalysis and trial sequential analysis. Anesth Analg. 2011;112:1411-21.

https://doi.org/10.1213/ANE.0b013e31820bd185

15. Gerlach H, Keh D, Semmerow A, Busch T, Lewandowski K, Pappert DM, Rossaint $R$, et al. Dose-response characteristics during long-term inhalation of nitric oxide in patients with severe acute respiratory distress syndrome: a prospective, randomized, controlled study. Am J Respir Crit Care Med. 2003;167:1008-15. https://doi.org/10.1164/rccm.2108121

16. Zimmerman JJ, Akhtar SR, Caldwell E, Rubenfeld GD. Incidence and outcomes of pediatric acute lung injury. Pediatrics. 2009;124(1):87-95. https://doi.org/10.1542/peds.2007-2462

17. Ichinose F, Roberts JD Jr, Zapol WM. Inhaled nitric oxide: a selective pulmo-nary vasodilator: current uses and therapeutic potential. Circulation. 2004;109:3106-11. https://doi.org/10.1161/01.CIR.0000134595.80170.62

18. Fan E, Mehta S. High-frequency oscillatory ventilation and adjunctive therapies: inhaled nitric oxide and prone positioning.Crit Care Med. 2005;33(3 Suppl):S182-7. https://doi.org/10.1097/01.CCM.0000155927.54034.34

19. Adhikari NK, Dellinger RP, Lundin S, Payen D, Vallet B, Gerlach $\mathrm{H}$, et al. Inhaled nitric oxide does not reduce mortality in patients with acute respiratory distress syndrome regardless of severity: systematic review and meta-analysis. Crit Care Med. 2014;42:404-12. https://doi.org/10.1097/CCM.0b013e3182a27909 